\title{
Nucleoside 5'-O-monophosphorothioates as modulators of the P2Y14 receptor and mast cell degranulation
}

\author{
Edyta Gendaszewska-Darmach ${ }^{1}$, Edyta Węgłowska ${ }^{1}$, Aurelia Walczak-Drzewiecka² \\ and Kaja Karaś ${ }^{1}$ \\ 1 Institute of Technical Biochemistry, Faculty of Biotechnology and Food Sciences, Lodz University of Technology, \\ Stefanowskiego, Lodz, Poland \\ ${ }^{2}$ Laboratory of Cellular Immunology, Institute of Medical Biology, Polish Academy of Sciences, Lodowa, Lodz, Poland \\ Correspondence to: Edyta Gendaszewska-Darmach, email: edyła.gendaszewska-darmach@p.lodz.pl \\ Keywords: P2Y receptors, nucleoside 5'-O-monophosphorothioates, inflammation, degranulation, RBL-2H3 cells, Immunology and \\ Microbiology Section, Immune response, Immunity \\ Received: May 12, $2016 \quad$ Accepted: September 24, $2016 \quad$ Published: October 09, 2016
}

\section{ABSTRACT}

Mast cells (MCs) are long-lived resident cells known for their substantial role in antigen-induced anaphylaxis and other immunoglobulin E-mediated allergic reactions as well as tumor promotion. MCs' activation results in the release of pro-inflammatory factors such as histamine, tryptase, tumor necrosis factor or carboxypeptidase $A$ stored in secretory granules. IgE-dependent hypersensitivity has been thought to be the major pathway mediating degranulation of mast cells, but the P2Y14 nucleotide receptor activated by UDP-glucose (UDPG) may also enhance this process. In this study we identified thymidine 5'-O-monophosphorothioate (TMPS) as a molecule inhibiting UDPG-induced degranulation in a rat mast cell line (RBL-2H3). Additionally, TMPS diminished UDPG-evoked intracellular calcium mobilization in a stable HEK293T cell line overexpressing the P2Y14 receptor. Therefore, we demonstrate that the use of thymidine 5'-O-monophosphorothioate might be a novel anti-inflammatory approach based on preventing mast cell activation.

\section{INTRODUCTION}

Mast cells (MCs) are a population of leukocytes derived from haematopoietic progenitor cells that are associated with hypersensitivity reactions. Once activated, mast cells release a lot of pro-inflammatory cytokines, including histamine, tumor necrosis factor, and serotonin stored in secretory granules [1]. These are critical agents in the pathogenesis of asthma, allergic rhinitis, mastocytosis, psoriasis, and the progression of numerous cancers [2]. An association between chronic inflammation and increased susceptibility to neoplastic transformation has been documented for many years [3]. Circulating mast cells precursors migrate into the developing tumor [4] and increased number of MCs was found in human lymphoid neoplasms [5], thyroid [6], prostate [7] or pancreatic cancers [8]. It has been also shown that histamine and chemokines (CXCL1/GRO- $\alpha$, CXCL10/IP10, and CXCL8/IL-8) released by activated human MCs modulate proliferation, survival, and invasion of thyroid cancer cells through the involvement of specific receptors
[9]. Thus, specific inhibitors focused on preventing mast cell activation might prospectively offer novel antiinflammatory therapeutic approaches.

Degranulation of mast cells can be evoked by immunoglobulin E (IgE) and non-immunologic agents [2]. Activation of high-affinity Ig E receptor (FceRI) plays an extremely important role in the release of pro-inflammatory mediators $[2,10]$. However, in a physiological setting, other receptors, such as P2Y family activated by nucleotides, might also markedly influence the release of mediators by mast cells $[11,12]$. P2Y nucleotide receptors (P2YR), belonging to $G$ proteincoupled receptors (GPCRs) include eight subtypes, namely P2Y1, P2Y2, P2Y4, P2Y6, P2Y11, P2Y12, P2Y13 and $\mathrm{P} 2 \mathrm{Y} 14$ [13]. $\mathrm{P} 2 \mathrm{Y} 1, \mathrm{P} 2 \mathrm{Y} 12$ and $\mathrm{P} 2 \mathrm{Y} 13$ receptors respond to ADP (ATP may be a partial agonist), but not to uracil nucleotides. P2Y2 is activated by both ATP and UTP, whereas P2Y6 preferentially by UDP. UTP is the $\mathrm{P} 2 \mathrm{Y} 4$ agonist while ATP activates the rat homologue of this receptor and antagonizes the human homologue [14, 15]. P2Y11 receptor is activated primarily by ATP, while 
P2Y14 responds to the nucleotide sugar conjugate UDPglucose (UDPG) and UDP $[16,17]$. It has been shown that UDP-glucose enhances antigen-induced release of $N$-acetyl- $\beta$-D-hexosaminidase (a granule enzyme that parallels histamine release) in rat RBL-2H3 and human LAD2 mast cells via the P2Y14R [11, 12]. P2Y14 receptor is involved not only in inflammatory, but also hypoxic and endocrine signalling and thus serves as an attractive pharmacological target $[18,19]$.

The P2Y14R has been considered a nucleotide sugar-activated purinergic receptor with a following order of potency observed: UDP-glucose $>$ UDP-galactose $>$ UDP-glucuronic acid > UDP-N-acetylglucosamine [20, $21,22]$. Chambers et al. reported that ADP-glucose, UMP, UDP, and UTP as well as uridine were unable to activate P2Y14 [21, 23]. The discovery by Carter et al. that UDP also acts as a potent agonist revealed that a sugar moiety is not required for activation of the $\mathrm{P} 2 \mathrm{Y} 14$ receptor. In those studies slight activities were observed with ADP, CDP, and GDP at concentrations greater than 100-fold higher than the concentrations of UDP producing a maximal response $[22,24]$. Hamel et al. [23] showed with conventional and nonconventional methods that even UMP selectively activated HEK cells coexpressing P2Y14 and Gaqi5. The presence of 2-thiouracil modification within UDPG and UDP amplified potency at the human P2Y14 receptor with an $\mathrm{EC}_{50}$ value of $11 \mathrm{~nm}$ and $1.92 \mathrm{nM}$, respectively, as compared to UDPG $\left(\mathrm{EC}_{50} 400 \mathrm{nM}\right)$ and $\operatorname{UDP}\left(\mathrm{EC}_{50} 160\right.$ nM) $[25,26]$.

Recently we have shown that nucleoside 5'-O-monophosphorothioate analogues, containing a sulfur atom in place of one of non-bridging oxygen atoms in a phosphate group (Figure 1), can act as ligands for P2Y6 receptor. We paid particular attention to the unique activity of thymidine 5'-O-monophosphorothioate (TMPS) which acts as a selective partial agonist of the P2Y6R [27]. Here we show that in HEK293T cells stably expressing P2Y14R uridine 5'-O-monophosphorothioate (UMPS), cytidine 5'-O-monophosphorothioate (CMPS), and adenosine 5 '- $O$-monophosphorothioate (AMPS) act as P2Y14 agonists while TMPS serves as an antagonist. Using rat basophilic leukemia RBL-2H3 cells where the P2Y14 receptor is endogenously expressed [11], we demonstrate that TMPS does not induce degranulation in opposition to UDPG, UMPS, CMPS, AMPS, and a selective P2Y14 receptor agonist, namely MRS 2690 (diphosphoric acid 1- $\alpha$-D-glucopyranosyl ester 2-[(4'-methylthio)uridin-5"-yl] ester). Moreover, UDPG- and MRS 2690-induced increase of $N$-acetyl$\beta$-D-hexosaminidase release can be blocked by TMPS pre-treatment. It may suggest that thymidine 5'-O-monophosphorothioate possesses unique activity to antagonize the P2Y14 receptor and inhibit mast cell degranulation. An additional advantage for the therapeutic potential of nucleoside 5'-O-monophosphorothioates is that replacing an oxygen atom with a sulfur in a phosphate group confers a significant resistance toward enzymatic hydrolysis catalyzed by numerous enzymes, including the ectonucleotide pyrophosphatase/phosphodiesterase family, the ecto-nucleoside triphosphate diphosphohydrolase family, and ecto-5'-nucleotidases [27, 28]. A phosphorothioate modification of nucleotides substantially prolongs their half-life and duration of action.

\section{RESULTS}

\section{Determination of RBL-2H3 cells viability}

Firstly, we determined the effects of nucleoside $5^{\prime}-O$-monophosphates and nucleoside 5'-O-monophosphorothioates on RBL-2H3 cell viability using a rezasurin-based assay. We compared the effects of unmodified uridine-containing P2Y14 agonists, namely UDP-glucose, UDP and UMP. Since we have recently shown that nucleoside 5'-O-monophosphorothioate analogues could act as P2Y receptor ligands, we also tested pyrimidine nucleotides (UMPS, TMPS, CMPS) serving as prime subjects of this research and adenosine 5'-O-monophosphorothioate (AMPS) as a purine control. After 24 hours of incubation all the compounds tested did not significantly inhibit cellular viability (Figure 2). Thus, one can assume that UDP-glucose and nucleoside<smiles>[X]C1OC(COP(=O)([O-])[S-])C(O)C1[X]</smiles>

\section{$\mathrm{X}: \mathrm{H}$ or $\mathrm{OH}$ \\ $Z$ : adenine, cytosine, thymine, uracil}

Figure 1: Structures of nucleoside 5'-O-monophosphorothioate analogues studied. 
5'-O-monophosphorothioate analogues do not possess cytotoxic properties exhibiting good safety profile even at the highest concentration used, namely $100 \mu \mathrm{M}$ and 1000 $\mu \mathrm{M}$.

Inhibitory effects of thymidine 5'-Omonophosphorothioate on UDPG- and MRS 2690induced $\beta$-HEX release from $\mathrm{RBL}-2 \mathrm{H} 3$ cells

Gao et al. previously showed that the P2Y14 receptor agonist (UDPG) alone was unable to induce $N$-acetyl- $\beta$-D-hexosaminidase ( $\beta$-HEX) release but it concentration-dependently enhanced antigen-induced degranulation [11]. $\beta$-HEX release was also used in our studies as an indicator of the RBL-2H3 degranulation. Therefore we first determined the relationship between FceR-mediated cell degranulation and the concentration of the antigen used (DNP-HSA). RBL-2H3 cells were primed with increasing concentrations of the antigen (1-1000 $\mathrm{ng} / \mathrm{ml})$ and the maximal $\beta$-HEX release $(29.46 \pm 9.92 \%$ ) was observed for DNP-HSA used at the concentration of $100 \mathrm{ng} / \mathrm{ml}$. Thus for further experiments submaximal concentration $(10 \mathrm{ng} / \mathrm{ml})$ of the antigen was chosen which proved to stimulate degranulation at the level of $6.28 \pm$ 4.76\% (Figure S1; Supplementary Materials).
Then we examined the influence of nucleotides on DNP-HSA-mediated $\beta$-HEX release in RBL-2H3 cells. As expected UDP-glucose significantly elevated antigen-induced degranulation. The maximal response was observed in the case of $10 \mu \mathrm{M}$ UDPG inducing degranulation at the level of $25.55 \pm 4.24 \%$ (Figure 3A). UDP, UMP, UMPS, CMPS, and AMPS also caused enhancement of $\beta$-HEX release. The only exception was TMPS in which case even at $1000 \mu \mathrm{M}$ concentration no degranulation over antigen alone was observed (Figure 3A). It might have suggested that UMPS, CMPS, and AMPS but not TMPS could activate the P2Y14 receptor.

During the next step cells were pre-incubated with the nucleotides tested for 10 minutes before the application of UDPG serving as the P2Y14 agonist. UDPG-induced increase of RBL-2H3 cell degranulation was blocked only in the case of pre-treatment with TMPS. Other nucleotides applied did not influence $\beta$-HEX release (Figure 3B). These results suggest that thymidine 5'-O-monophosphorothioate may antagonize the P2Y14 receptor. To examine whether inhibition RBL-2H3 cell degranulation by TMPS was specifically mediated via the P2Y14 we used a selective P2Y14 receptor agonist, namely MRS 2690 (diphosphoric acid 1- $\alpha$-D-glucopyranosyl ester 2-[(4'-methylthio)

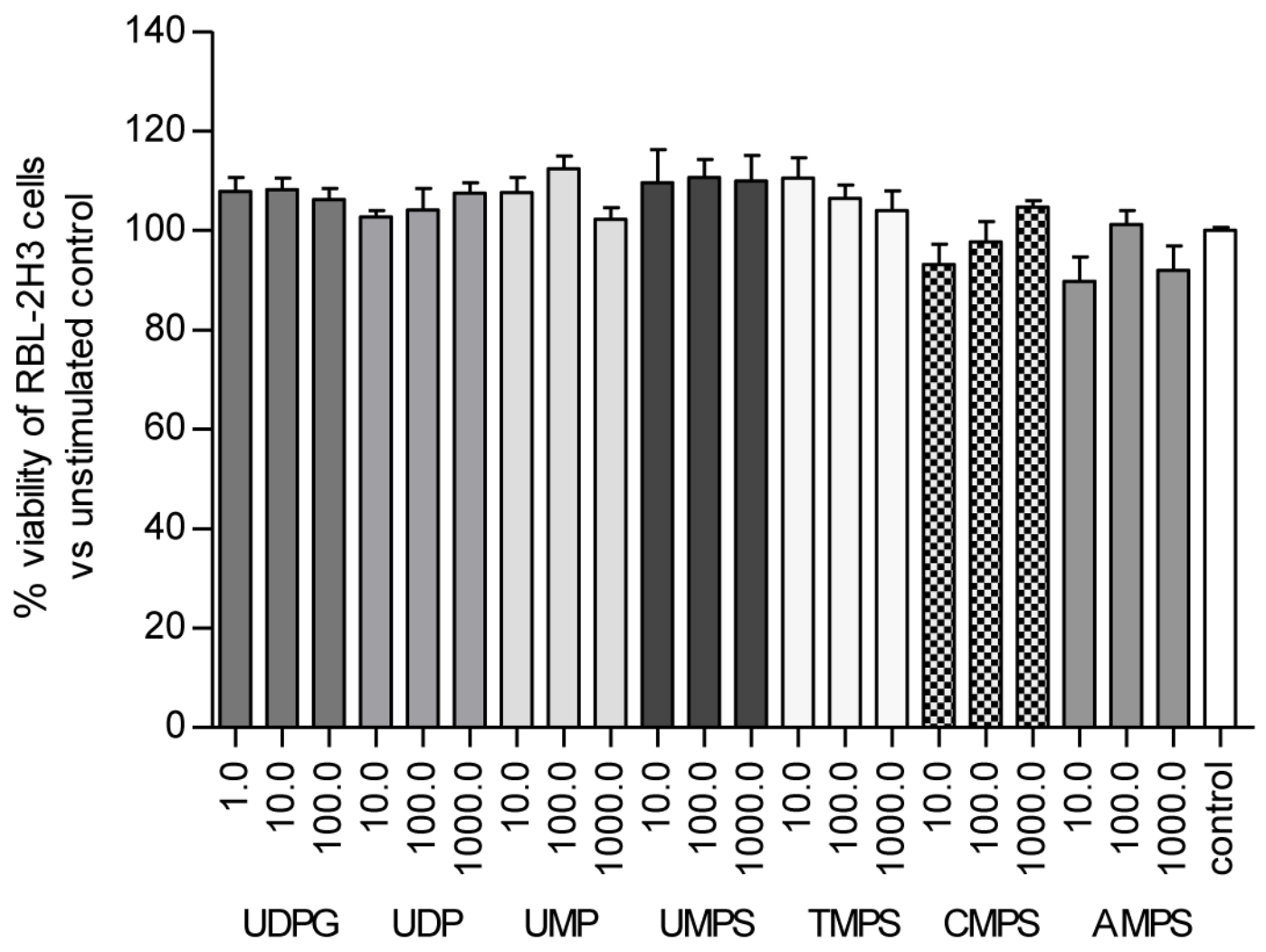

Figure 2: The effect of UDPG $(1.0 \mu \mathrm{M} ; 10.0 \mu \mathrm{M} ; 100.0 \mu \mathrm{M})$, UMP and nucleoside 5'-O-monophosphorothioates (10.0 $\mu \mathrm{M} ; 100.0 \mu \mathrm{M} ; 1000.0 \mu \mathrm{M})$ on the viability of RBL-2H3 cells. Viability was assessed using PrestoBlue kit after $24 \mathrm{~h}$ of incubation. Data represent the means \pm SD from at least three independent experiments; ${ }^{*} p<0.05 v s$ unnstimulated control cells $(100 \%)$. 

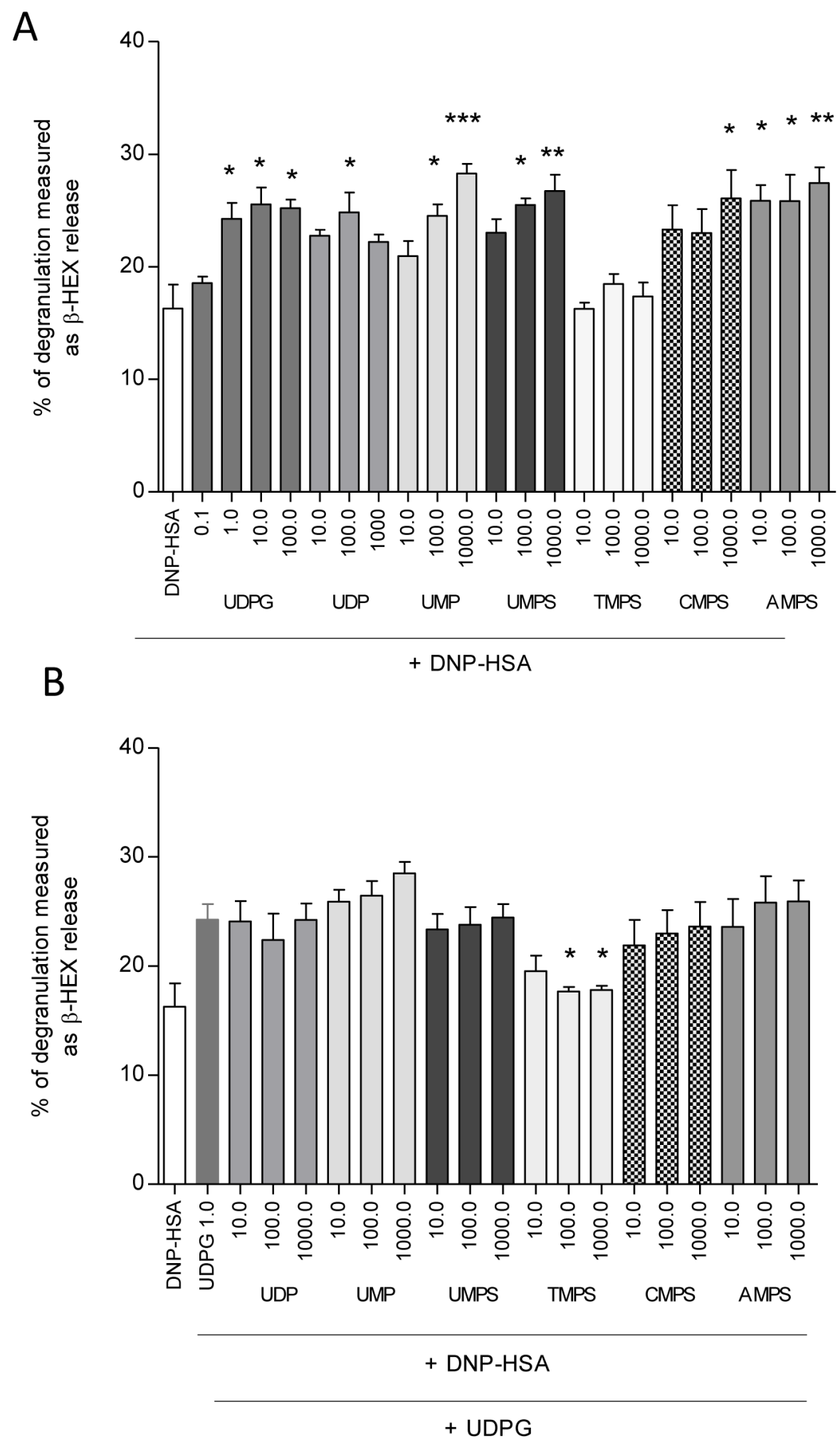

Figure 3: The influence of UDPG $(0.1 \mu \mathrm{M} ; 1.0 \mu \mathrm{M} ; 10.0 \mu \mathrm{M} ; 100.0 \mu \mathrm{M}), \mathrm{UMPand}$ nucleoside 5'- $O$-monophosphorothioates $(10.0 \mu \mathrm{M} ; 100.0 \mu \mathrm{M} ; 1000.0 \mu \mathrm{M})$ on $\beta$-HEX release from RBL-2H3 cells. Mast cells were sensitized for $24 \mathrm{~h}$ with DNP-specific $\operatorname{IgE}$ antibody $(0,5 \mu \mathrm{g} / \mathrm{ml})$ and incubated for $20 \mathrm{~min}$ with antigen in the presence of tested nucleotides used at the concentration of A. For antagonist assay, cells were pre-incubated with the compounds $(10.0 \mu \mathrm{M} ; 100.0 \mu \mathrm{M} ; 1000.0 \mu \mathrm{M})$ for 10 minutes before the application of UDPG $(1.0 \mu \mathrm{M})$ serving as the control agonist B. The spontaneous release $(9.5 \%)$ was subtracted from the final data. Data represent the means $\pm \mathrm{SD}$ from at least three independent experiments; ${ }^{*} p<0.05,{ }^{*} p<0.1$. ${ }^{* * *} p<0.001$ when compared to DNP-HSA (A) or DNPHSA with $1.0 \mu \mathrm{M} \mathrm{UDPG}$ (B). 
uridin-5"-yl] ester) possessing 7-fold higher potency than UDPG [25]. Figure 4 shows that MRS 2690 itself increased antigen-induced $\beta$-HEX release in a concentration-dependent manner and 10-minute pretreatment with TMPS significantly diminished MRS 2690 caused enhancement. The results have proved that thymidine 5'-O-monophosphorothioate plays an important role in inhibiting mast cell degranulation via antagonizing of the P2Y14 receptor

\section{Intracellular calcium mobilization assay in RBL-2H3 cells}

Gao et al. [11] showed that UDP-glucose not only enhanced degranulation process but also elevated intracellular calcium ions level with $\mathrm{EC}_{50}$ value of 5980 $\pm 1140 \mathrm{nM}$ in RBL-2H3 mast cells. We applied a Fluo8 probe to determine $\left[\mathrm{Ca}^{2+}\right]_{\mathrm{i}}$ changes upon nucleoside 5'-O-monophosphorothioates treatment. The relative fluorescent units (RFU) were monitored for 180 seconds. In our studies stimulation with UDPG as well as AMPS, UMPS, CMPS and TMPS increased cytosolic $\mathrm{Ca}^{2+}$ concentration. The peak heights were parallel with the final nucleotide concentration. At $1 \mathrm{mM}$ concentration adenosine 5'-O-monophosphorothioate evoked the highest elevation of $\left[\mathrm{Ca}^{2+}\right]_{\mathrm{i}}$ followed by UDPG, UMPS, TMPS, and CMPS. UMP was also shown to induce intracellular calcium flux, but to a lower extend (Figure 5).

Among nucleoside 5'-O- monophosphorothioates tested in this study only TMPS behaved as an inhibitor of degranulation process. Therefore we employed once again the selective P2Y14 agonist and pre-incubated RBL-2H3 cells with thymidine 5'-O- monophosphorothioate before

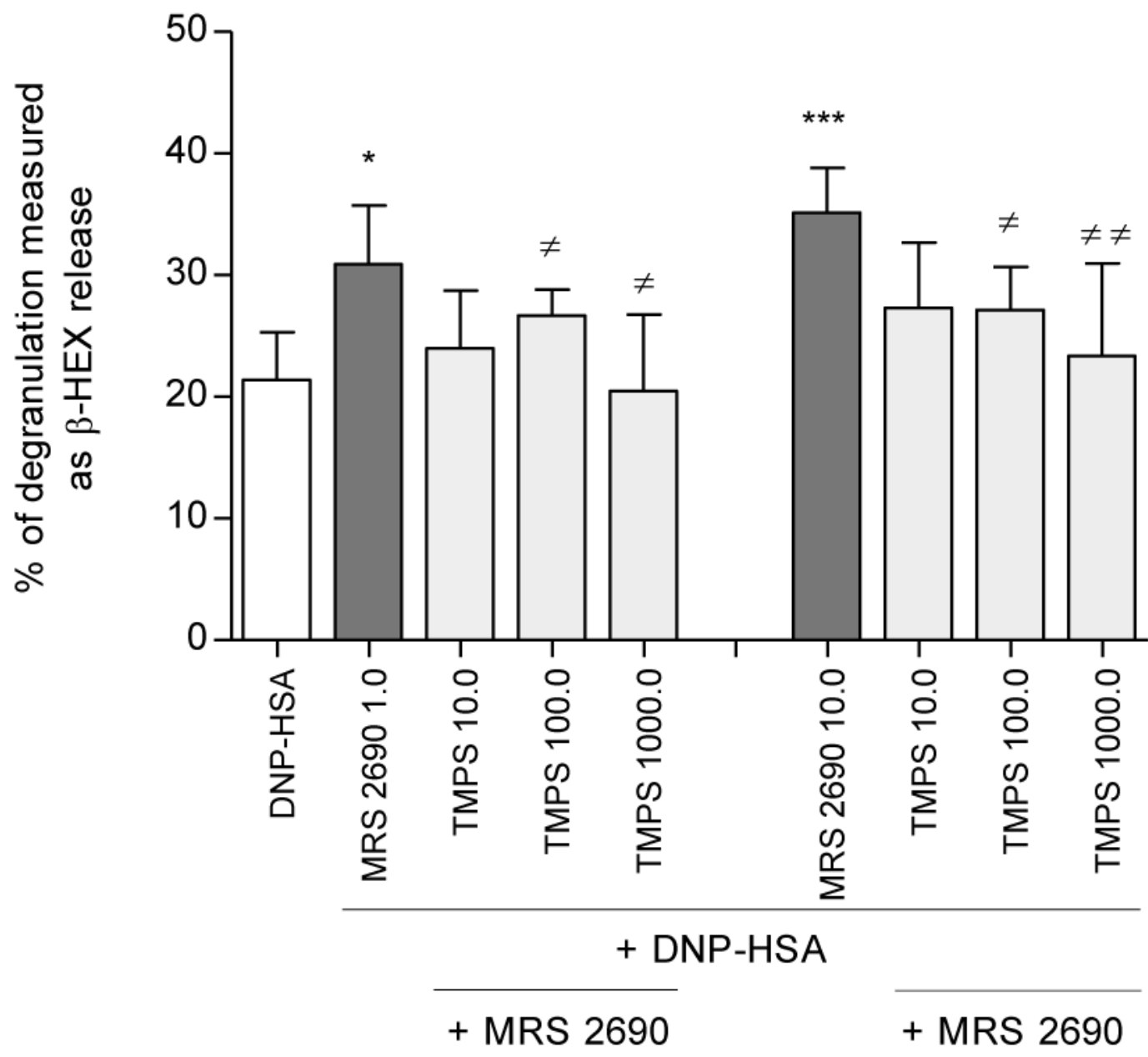

Figure 4: The influence of TMPS pre-treatment $(10.0 \mu \mathrm{M} ; 100.0 \mu \mathrm{M} ; 1000.0 \mu \mathrm{M})$ on MRS 2690-induced (1.0 $\mu \mathrm{M} ; 10.0$ $\boldsymbol{\mu M )} \boldsymbol{\beta}$-HEX release from RBL-2H3 cells. Mast cells were sensitized for $24 \mathrm{~h}$ with DNP-specific IgE antibody $(0,5 \mu \mathrm{g} / \mathrm{ml})$ and $\mathrm{pre}-$ incubated with TMPS for 10 minutes before the application of MRS 2690 serving as the control agonist. The spontaneous release (9.5\%) was subtracted from the final data. Data represent the means $\pm \mathrm{SD}$ from at least three independent experiments; $* p<0.05, * * * p<0.001$ when compared to DNP-HSA or $\neq p<0.05, \neq \neq p<0.01$ when compared to MRS 2690 . 
Table 1: Nucleoside 5'-O-monophosphorothioates-dependent intracellular calcium response in HEK293T cells stably expressing human P2Y14 receptor (\% activation as compared to the maximal response evoked by control agonist UDPG used at a concentration of $1.0 \mu \mathrm{M})$

CONCENTRATION

\begin{tabular}{lllll}
\multicolumn{1}{c}{ NUCLEOTIDE } & $1000 \mu \mathrm{M}$ & $100 \mu \mathrm{M}$ & $10 \mu \mathrm{M}$ & $1 \mu \mathrm{M}$ \\
\cline { 2 - 5 } & $7.60 \pm 5.38$ & $\mathrm{NE}$ & $\mathrm{NE}$ & $\mathrm{NE}$ \\
TMPS & $102.5 \pm 7.14^{*}$ & $84.4 \pm 17.63^{*}$ & $33.6 \pm 15.81^{*}$ & $6.8 \pm 3.35$ \\
AMPS & $91.8 \pm 2.08^{*}$ & $89.1 \pm 6.47^{*}$ & $80.7 \pm 12.97^{*}$ & $84.5 \pm 5.34^{*}$ \\
UMPS & $72.6 \pm 5.81^{*}$ & $77.5 \pm 4.40^{*}$ & $\mathrm{NE}$ & $\mathrm{NE}$
\end{tabular}

Calcium mobilization assay in HEK293T cells expressing human P2Y14 receptor was performed by Multispan Inc. (details in Materials and Methods). NE: no effect. Data represent the average \pm SD of at least triplicate determinations. ${ }^{*} p<0.05$ test

Table 2: UDPG-induced intracellular calcium response in HEK293T cells stably expressing human P2Y14 receptor after 10-minute pre-treatment with nucleoside $5^{\prime}-O$-monophosphorothioates $(\%$ activation as compared to the $100 \%$ effect evoked by a control agonist used at a concentration of $\mathrm{EC}_{80}$ concentration corresponding to $0.22 \mu \mathrm{M}$ )

\section{CONCENTRATION}

\begin{tabular}{lcccc}
\cline { 3 - 5 } NUCLEOTIDE & $\mathbf{1 0 0 0} \boldsymbol{\mu M}$ & $\mathbf{1 0 0} \boldsymbol{\mu M}$ & $\mathbf{1 0} \boldsymbol{\mu M}$ & $\mathbf{1} \boldsymbol{\mu M}$ \\
\hline TMPS & $17.30 \pm 52.94 *$ & $72.30 \pm 15.73^{*}$ & $75.41 \pm 16.61^{*}$ & $98.83 \pm 8.67$ \\
AMPS & $5.71 \pm 1.84 *$ & $1.51 \pm 0.51^{*}$ & $55.80 \pm 21.19^{*}$ & $93.72 \pm 1.02$ \\
UMPS & $35.60 \pm 7.81^{*}$ & $37.0 \pm 8.82^{*}$ & $43.80 \pm 8.70^{*}$ & $47.31 \pm 11.46^{*}$ \\
CMPS & $15.0 \pm 1.33^{*}$ & $12.1 \pm 1.60^{*}$ & $97.70 \pm 9.84$ & $96.63 \pm 8.67$
\end{tabular}

Calcium mobilization assay in HEK293T cells expressing human P2Y14 receptor was performed by Multispan Inc. (details in Materials and Methods). Data represent the average \pm SD of at least triplicate determinations. ${ }^{*} p<0.05$ test

applying MRS 2690 and measuring intracellular calcium concentration. Figure 6 shows that TMPS treatment significantly blunted the increase of intracellular $\mathrm{Ca}^{2+}$ concentration evoked by MRS 2690, consistently with an antagonist function of TMPS for the P2Y14R.

\section{Calcium mobilization assay in HEK293T cells stably expressing individual P2Y14 receptor}

To prove ultimately that nucleoside 5'-Omonophosphorothioates are ligands for the $\mathrm{P} 2 \mathrm{Y} 14$ receptor a stable HEK293T cell line co-expressing the P2Y14R and the chimeric G-protein Gaqi5 was employed. Cells were probed with AMPS, UMPS, CMPS and TMPS to monitor stimulation of intracellular calcium mobilization. Surprisingly, among the nucleotide analogues studied at the concentration of $1 \mathrm{mM}$ the most potent appeared to be a purine nucleotide, namely adenosine 5'-O-monophosphorothioate with a maximal response corresponding to $102.5 \pm 7.1 \%$ of the maximal response induced by $1.0 \mu \mathrm{M}$ UDPG . The rank order of potency was as follows: AMPS > UMPS > CMPS. The treatment with $1 \mathrm{mM}$ TMPS failed to elicit a substantial calcium response from the stable HEK293T cell line expressing P2Y14R. At lower concentrations the most potent nucleotide was uridine 5'-O-monophosphorothioate, e.g. when $1.0 \mu \mathrm{M}$ concentration was applied the observed effect corresponded to $84.5 \pm 5.3 \%$ of the maximal response induced by $10.0 \mu \mathrm{M}$ UDPG (Table 1 ).

In antagonist assay, AMPS, UMPS and CMPS displayed dose-dependent antagonist activity that could be due to desensitization of the receptor since the earlier studies without pre-incubation did not show antagonist activity. At $10 \mu \mathrm{M}$ concentration applied CMPS did not show any antagonistic activity in opposite to AMPS and UMPS lowering UDPG response to the level of $55.8 \pm 21.2 \%$ and $43.8 \pm 8.7 \%$, respectively. The most interesting effect was observed in the case of thymidine 5'-O-monophosphorothioate that inhibited UDPG-induced effect despite the lack of P2Y14R agonist activity (Table 2 ). These results confirm once again that TMPS might act as an antagonist for the $\mathrm{P} 2 \mathrm{Y} 14$ receptor.

Discussion

Several studies indicate a pro-inflammatory role for the P2Y14 receptor found on its high expression level in immune cells, and on the increased release of UDPglucose, by damaged cells $[19,29,30]$. UDPG enhances 

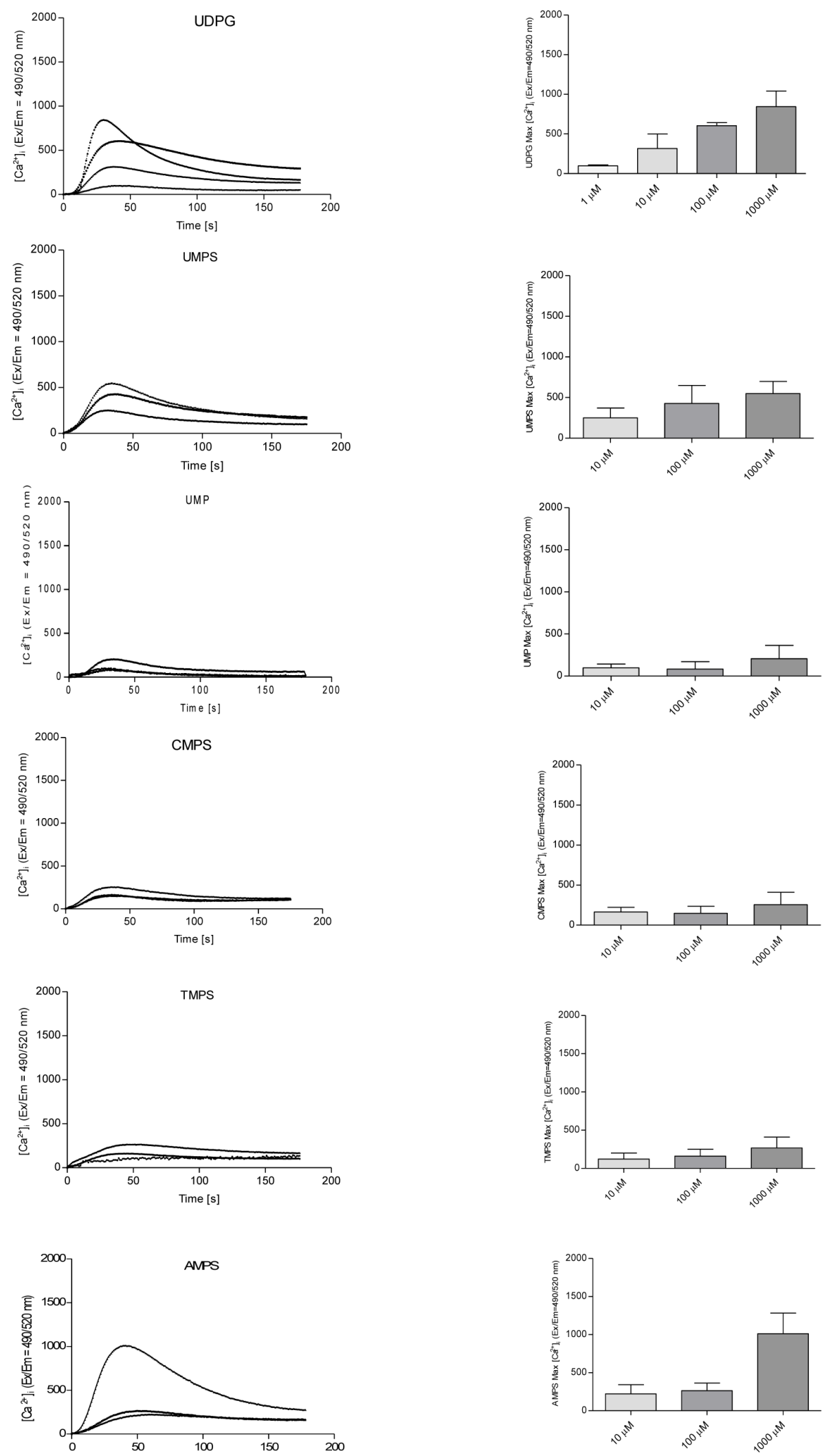

Figure 5: Stimulation of intracellular calcium mobilization in RBL-2H3 cells by UDPG (1.0 $\mu$ M; $10.0 \mu M ; 100.0 \mu M$; 1000.0 $\boldsymbol{\mu M})$, UMP and nucleoside 5'-O-monophosphorothioates (10.0 $\boldsymbol{\mu M}$; $100.0 \mu M ; 1000.0 \mu M)$. Left panel represents time course of mean $\mathrm{Ca}^{2+}$ responses (Fluo-8 ratio) and right panel demonstrates the maximal fluorescence intensity obtained from traces shown in the left panel. Obtained results represent the means from at least three independent experiments. 
A

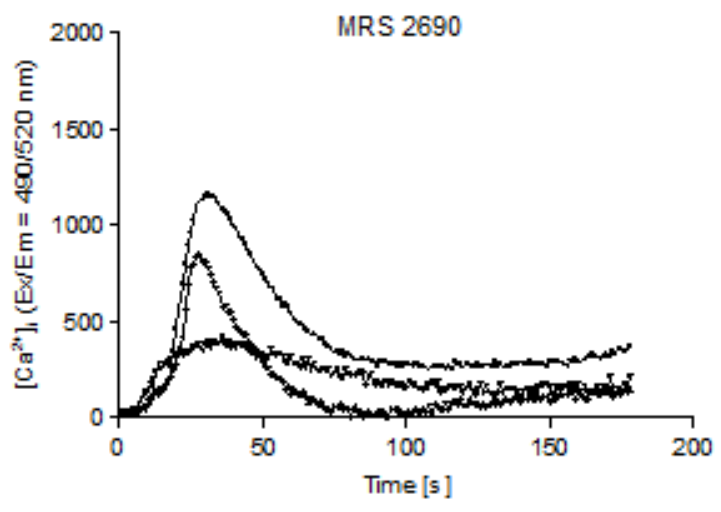

C

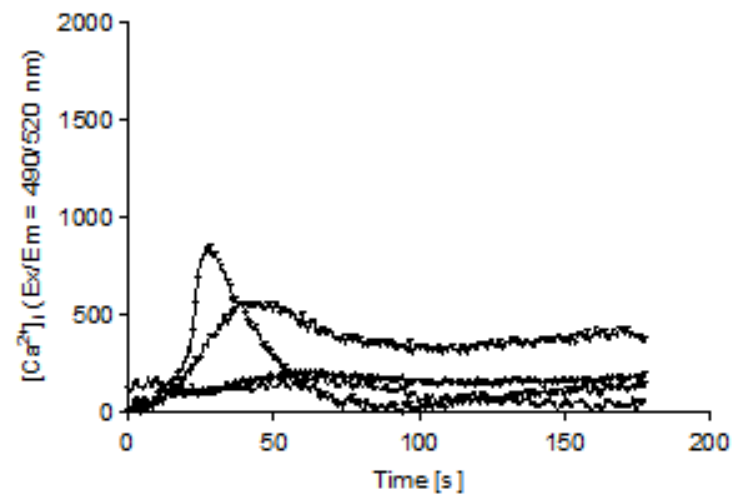

B

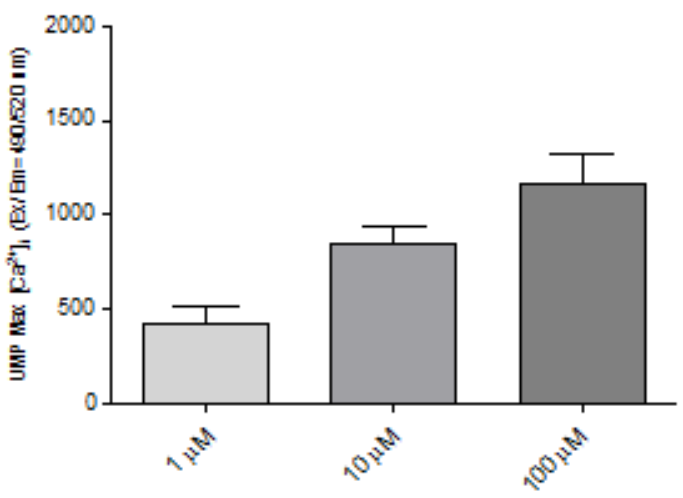

D

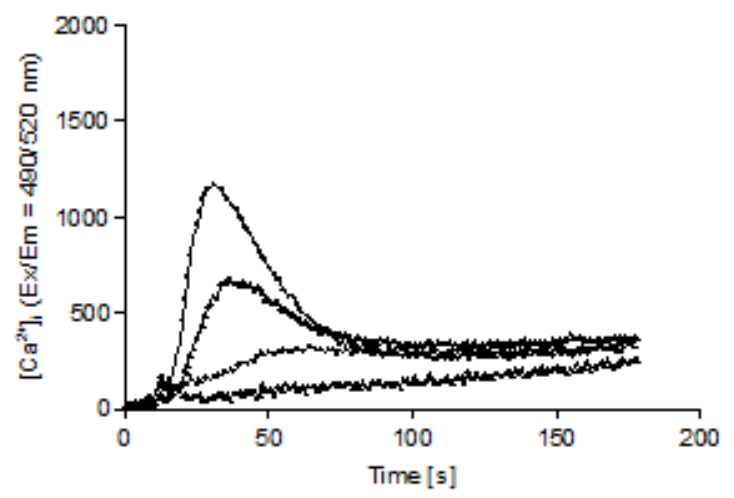

$\mathrm{E}$

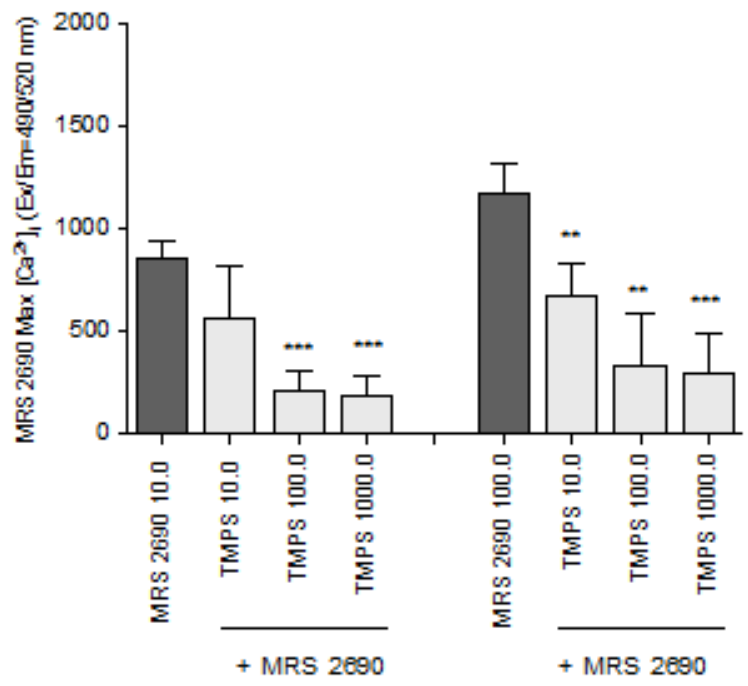

Figure 6: Stimulation of intracellular calcium mobilization in RBL-2H3 cells by MRS $2690(1.0 \mu M ; 10.0 \mu M ; 100.0$ $\mu \mathrm{M})$ and the effect of TMPS pre-treatment $(10.0 \mu \mathrm{M} ; 100.0 \mu \mathrm{M} ; 1000.0 \mu \mathrm{M})$. A. Time course of mean $\mathrm{Ca}^{2+}$ responses (Fluo-8 ratio) after MRS 2690 application; B. The maximal fluorescence intensity obtained from traces shown in A; C. The influence of TMPS pretreatment on MRS 2690 -induced $(10.0 \mu \mathrm{M})$ calcium mobilization; D. The influence of TMPS pre-treatment on MRS 2690-induced $(100.0 \mu \mathrm{M})$ calcium mobilization; E. the maximal fluorescence intensity obtained from traces shown in C and D. Data represent the means $\pm \mathrm{SD}$ from at least three independent experiments; ${ }^{*} p<0.05,{ }^{* *} p<0.01 * * * p<0.001$ when compared to MRS 2690. 
the mobility of neutrophils [31, 32] and expression of $\mathrm{P} 2 \mathrm{Y} 14 \mathrm{R}$ in rat brain was shown to be up-regulated by immunologic challenge with lipopolysaccharide [33]. Besides, UDP-glucose release from hepatocellular injury may trigger innate immune responses and promote the development of insulin resistance [34]. What is more, UDP-glucose was shown to occur at high levels in cancer cells [35]. Thus, UDP-glucose is regarded as a pro-inflammatory factor and novel therapeutic strategies that inhibit P2Y14R may prove to be protective to the development of inflammatory processes.

The P2Y14R has been deliberated a nucleotide sugar-activated receptor for which UDP-glucose is the most active ligand $[30,36]$. In contrast to other studies Carter et al. demonstrated that uridine diphosphate acted also as agonist of human P2Y14R [22]. Intracellular calcium mobilization and nonconventional cellular impedance functional assays showed that UMP, UDP, and UTP uncoupled to glucose also activated P2Y14expressing cells [23].

Non-nucleotide dihydropyridopyrimidine [37] and naphthoic acid-containing [38] molecules were developed as potential P2Y14R inhibitors. Optimization of the latter compound revealed that 4-((piperidin-4-yl)-phenyl)-7-(4(trifluoromethyl)-phenyl)-2-naphthoic acid (PPTN) acts as a high-affinity competitive antagonist of the P2Y14R [39]. Unfortunately, further studies demonstrated that PPTN had a high affinity towards serum proteins $[40,41]$. Despite the fact that the 2-naphthoic acid class displays poor druglike characteristics due to high molecular weight and high lipophilicity, such compounds can be used to develop high-affinity P2Y14R fluorescent probes for receptor detection and characterization [42].

Nucleoside 5'-O-monophosphates were not thought to act as agonists of the nucleotide receptors. However, Hamel et al. demonstrated that UMP selectively activated the P2Y14 receptor, although nucleotide diphosphates were more potent than monophosphates. The rank order of potencies was as follows: UDPG $\approx \mathrm{UDP}>\mathrm{UTP}>\mathrm{UMP}$. Other nucleoside 5'-O-monophates tested (AMP, CMP, GMP, and TMP) had $\mathrm{IC}_{50}$ above the concentration range tested ( > $20000 \mathrm{nM}$ ) [23].

In this study, we analyzed the potential of various nucleoside 5'-O-monophosphorothioates as modulators of the P2Y14 receptor and mast cell degranulation. Stimulation with the tested nucleotides increased cytosolic $\mathrm{Ca}^{2+}$ concentration in RBL-2H3 cells suggesting activation of nucleotide receptors. Indeed, Gao et al. [11, 43] demonstrated the existence of receptors for uridine nucleotides (P2Y2, P2Y4, P2Y6, P2Y14) and P2Y receptor subtypes that respond to ADP (P2Y1, P2Y2, $\mathrm{P} 2 \mathrm{Y} 13)$ on the surface of RBL-2H3 cell line. The P2Y12 receptor was undetectable while the gene expression of the P2Y11R could not be measured, due to the lack of this subtype in rodents./as this subtype is not present in rodents.

Very recently we have shown that pyrimidine nucleoside 5'-O-monophosphorothioates are P2Y6 agonists. Although TMPS and UMPS are weaker agonists than uridine 5'-O-(2-thiodiphosphate), their P2Y6dependent increase in HeLa cell migration is comparable with the effect generated by UDP $\beta S$ [27]. AMPS appeared to be inactive as a P2Y6 agonist, however acted as a partial agonist of $\mathrm{P} 2 \mathrm{Y} 11$ receptor [44].

To confirm a direct interaction between the P2Y14 receptor and nucleoside 5'-O-monophosphorothioates a stable HEK293T cell line co-expressing the P2Y14R and the chimeric G-protein Gaqi5 was employed. These HEK293T cells responded to AMPS, UMPS, CMPS but not to TMPS with large, concentration-dependent intracellular $\mathrm{Ca}^{2+}$ increase. The loss of agonist activity of TMPS molecule can be explained by the fact that 2 ' and $3^{\prime}$ hydroxyl groups of the ribose moiety were shown by Trujillo et. al. to be crucial for the P2Y14R activation. Deoxynucleotides are not able to form the necessary H-bonding interactions as in the case of the ribonucleotides [45]. Therefore, to confirm this suggestion, we compared the influence of two adenine-containing phosphorothioates (AMPS and dAMPS) on degranulation of the RBL-2H3 cells and, as it could have been expected, the latter compound was inactive (unpublished data).

In parallel, in a stable P2Y14-expressing HEK293T cell line, thymidine 5'-O- monophosphorothioate inhibited UDPG-induced activation of P2Y14R suggesting that it might act as an antagonist. This hypothesis was confirmed with $N$-acetyl- $\beta$-Dhexosaminidase release method monitoring mast cell degranulation. TMPS suppressed UDPG-evoked degranulation in antigen-sensitized RBL-2H3 cells. TMPS also inhibited degranulation process stimulated by the selective P2Y14 receptor agonist, namely MRS 2690. At the same time TMPS treatment significantly blunted the increase of intracellular $\mathrm{Ca}^{2+}$ concentration evoked by MRS 2690, consistently with an antagonist function of TMPS for the P2Y14R.

Recently, Trujillo et. al. have tried to explain structure-activity relationships of numerous synthetic analogues and their affinity to P2Y14 receptor. In their opinion the P2Y14R binding site contains so called bifurcated binding pocket, where the first subpocket is responsible for the binding of a nucleotide residue and the second one binds glycosyl moiety. According to the authors, the second subpocket is a structurally permissive region able to accept numerous conformations of the pyranose ring [46]. Our results regarding antagonistic properties of TMPS confirm their conclusion on the permissive subpocket, because even without the pyranose ring the binding of a nucleotide and a display of its agonistic or antagonistic activity occurs.

Moreover, Trujillo et al. indicated two amino 
acid residues (R253 and Q260) as those responsible for the binding of $\alpha$ phosphate group of UGP-glucose [45]. We suggest that one of them (arginine R253) is (can be) involved in hydrogen bonding with sulfur atom of the phosphorothioate group. Some structural studies on phosphorothioate oligonucleotide-proteins complexes indicate an involvement of arginine residue in formation of H••-S-P hydrogen bonds which are more potent that

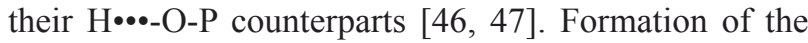
potent charge-assisted hydrogen bonds which involve negatively charged sulfur atom could explain much higher agonistic or antagonistic activities of nucleoside monophosphorothioates (UMPS, AMPS, TMPS) compared to their unmodified counterparts.

In our opinion, identification of TMPS as the P2Y14 antagonist is an interesting and unexpected finding because even recently it was concluded that nucleotide antagonists of the P2Y14 receptor had not been reported yet [45]. We propose that thymidine 5'-O-monophosphorothioate may be a new candidate, especially that it acts as an multifunctional ligand being a partial agonist of the P2Y6R and antagonist of P2Y14. Besides the increased stability of all nucleoside 5'-O-monophosphorothioates as compared to their unmodified counterparts may be responsible for their prolonged action.

\section{MATERIALS AND METHODS}

\section{Materials and tested compounds}

Nucleotides and their phosphorothioate analogues were purchased from the following sources: UDP, UMP and UDPG from Sigma-Aldrich (Saint Louis, MO, USA) and AMPS, CMPS, TMPS, and UMPS from BioLog (Bremen, Germany). The P2Y14 receptor-selective agonist MRS 2690 was provided by Tocris Bioscience (Bristol, UK). Dinitrophenyl conjugated bovine serum albumin (DNP-HSA) and p-nitrophenyl-N-acetyl- $\beta$-Dglucopyranoside were obtained from Sigma-Aldrich.

\section{Cell culture}

The rat basophilic leukemia RBL-2H3 cell line was purchased from Leibniz Institute DSMZ - German Collection of Microorganisms and Cell Cultures (Braunschweig, Germany). Cells were cultured in medium consisting of $70 \%$ MEM, 20\% RPMI 1640, 10\% fetal bovine serum containing $100 \mathrm{IU} / \mathrm{ml}$ penicillin and 100 $\mu \mathrm{g} / \mathrm{ml}$ streptomycin. All reagents for cell culture were obtained from Life Technologies (Carlsbad, CA, USA). Cells were incubated at $37^{\circ} \mathrm{C}$ in a humidified atmosphere of $95 \%$ air and $5 \% \mathrm{CO}_{2}$.

\section{Cell viability assay}

RBL-2H3 cells were seeded into 96-well plates in the number of $5 \times 10^{3}$ per well in complete medium. After $24 \mathrm{~h}$ of incubation, the medium in each well was supplemented with a respective nucleotide added to a final concentration of $100 \mu \mathrm{M}$. Cells were incubated in the presence of the investigated compounds for another 24 h. Following incubation, $10 \mu \mathrm{l}$ of PrestoBlue cell viability reagent (Life Technologies, Van Allen Way, CA, USA), a resazurin-based solution, was added into each well and incubated further for $80 \mathrm{~min}$ at $37^{\circ} \mathrm{C}$ and $5 \% \mathrm{CO}_{2}$. Cell viability was determined by measuring the fluorescent signal $\mathrm{F}_{530 / 590}$ on a Synergy 2 Microplate Reader (Bio-Rad, CA, USA). The obtained fluorescence magnitudes were used to calculate cell viability expressed as a percent of the viability of the untreated control cells.

\section{Calcium mobilization assay in HEK293T cells stably expressing the individual P2Y14 receptor}

Cell-based assays for activation of the P2Y14 receptor were performed by Multispan Inc. (Hayward, CA, USA). Briefly, HEK293T Gaqi5 cells with stable expression of the P2Y14R were seeded in 384-well blackwall, clear-bottom plates at a density of 20000 cells per well in $20 \mu \mathrm{L}$ of growth medium. $\mathrm{Ca}^{2+}$ flux assays were conducted after overnight culture according to the manufacturer's protocol using ScreenQuest ${ }^{\mathrm{TM}}$ Fluo-8 No Wash Calcium Assay kit (AAT Bioquest, Sunnyvale, CA, USA). Dye loading buffer was added to the cells and incubated for 60 minutes at $37^{\circ} \mathrm{C}$. Calcium flux was monitored for 90 seconds after compound's application. In the case of antagonist activity, cells were preincubated with the compounds at room temperature for 10 minutes before the application of UDPG serving as the control agonist.

The relative fluorescent units intensity values $(\Delta$ RFU) were calculated from maximal fluorescence reading after subtracting the average value of baseline reading.

The percentage of activation by a given compound was calculated from the following equation:

$\%$ activation $=(\triangle \mathrm{RFUCompound}$ $-\triangle$ RFUBackground $) /(\triangle$ RFUAgonist control $\Delta$ RFUBackground $)\} \cdot 100$

\section{Calcium flux assay in RBL-2H3 cells}

For intracellular $\mathrm{Ca}^{2+}$ measurement RBL-2H3 cells were seeded into 96 -well plates $\left(3.5 \times 10^{4}\right.$ cells per well) in $100 \mu 1$ of culture medium and incubated overnight under standard culture conditions. The next day cells were washed two times with $200 \mu \mathrm{L}$ of Hank's Balanced Salt Solution (Life Technologies) and $\left[\mathrm{Ca}^{2+}\right]_{\mathrm{i}}$ level was 
assessed after stimulation with tested compounds with the Screen Quest ${ }^{\mathrm{TM}}$ Fluo-8 No Wash Calcium Assay Kit (AAT Bioquest, Sunnyvale, CA, USA) according to the supplier's protocol. Calcium mobilization was monitored by the change in fluorescence $(\mathrm{Ex} / \mathrm{Em}=490 / 520 \mathrm{~nm})$ following stimulation and with respect to the background fluorescence on a Synergy 2 Microplate Reader. In the case of antagonist activity, cells were preincubated with TMPS at room temperature for 10 minutes before the application of MRS 2690 serving as the control P2Y14 agonist.

\section{Measurement of $N$-acetyl- $\beta$-D-hexosaminidase $(\beta-H E X)$ release from $\mathrm{RBL}-2 \mathrm{H} 3$ cells}

RBL-2H3 mast cells suspended in complete growth medium supplemented with DNP-specific IgE antibody $(0,5 \mu \mathrm{g} / \mathrm{ml})$ were spited into 96 -well plates and incubated overnight. Then cells were washed two times with $200 \mu \mathrm{L}$ of Hank's Balanced Salt Solution. Cells were incubated for $20 \mathrm{~min}$ with DNP-HSA (10 $\mathrm{ng} / \mathrm{ml})$ in the absence or presence of the compounds tested. In the case of antagonist activity, cells were preincubated with the compound at room temperature for 10 minutes before the application of UDPG and MRS 2690 serving as the control agonists.

The $N$-acetyl- $\beta$-D-hexosaminidase enzymatic activity of the supernatants and cell lysates (after addition of $0.1 \%$ Triton $\mathrm{X}-100$ ) was determined using $p$-nitrophenyl- $N$-acetyl- $\beta$-D-glucopyranoside $(8 \mathrm{mM})$ in $0.08 \mathrm{M}$ citric buffer ( $\mathrm{pH} 4.5)$ as chromogenic substrate. The enzymatic reaction was stopped by addition of $\mathrm{NaOH}$. The experimental results were gathered by absorbance measurements at $405 \mathrm{~nm}$ vs. $492 \mathrm{~nm}$ using a Synergy 2 Microplate Reader. $\beta$-HEX release was calculated using the following formula: Release $(\%)=$ (Supernatant Blank)/(Total - Blank) $\times 100$ and is presented after subtraction of the spontaneous release.

\section{Statistical analysis}

All data are presented as the mean \pm S.D. Levels of significance were analyzed by one-way ANOVA with Bonferroni post-test. Statistical significance was determined when P-value was less than 0.05. Differences between groups were rated significant at a probability error $P<0.05(*), P<0.01(* *)$, and $P<0.001(* * *)$.

\section{List of abbreviations}

AMPS, adenosine 5'-O-monophosphorothioate; CMPS, cytidine 5'-O-monophosphorothioate; FceRI, high-affinity immunoglobulin E receptor; DNP-HSA, dinitrophenyl conjugated human serum albumin; $\beta$-HEX, $N$-acetyl- $\beta$-D-hexosaminidase; MCs, mast cells;
MRS 2690 (diphosphoric acid 1- $\alpha$-D-glucopyranosyl ester 2-[(4'-methylthio)uridin-5'"-yl] ester); PPTN, 4-((piperidin-4-yl)-phenyl)-7-(4-(trifluoromethyl)-

phenyl)-2-naphthoic acid; TMPS, thymidine 5'-O-monophosphorothioate; UDPG, UDP-glucose; UMPS, uridine 5'-O-monophosphorothioate; $\left[\mathrm{Ca}^{2+}\right]_{\mathrm{i}}$, intracellular $\mathrm{Ca}^{2+}$ concentration

\section{Highlights}

Thymidine 5'-O-monophosphorothioate inhibits mast cell degranulation

Thymidine 5'-O-monophosphorothioate antagonizes the $\mathrm{P} 2 \mathrm{Y} 14$ receptor

The enhancement of intracellular calcium concentration by nucleoside 5 '- $O$-monophosphorothioates appears to be mediated via multiple $\mathrm{P} 2 \mathrm{Y}$ receptors present on RBL-2H3 cells

\section{CONFLICT OF INTEREST}

The authors confirm that this article content has no conflict of interest.

\section{GRANT SUPPORT}

This study was supported by the grant from the Ministry of Science and Higher Education (Project No. N 405304736 ).

\section{DEDICATION} birthday.

In honour of Professor Stanislaw Bielecki's 70th

\section{REFERENCES}

1. Theoharides TC, Alysandratos KD, Angelidou A, Delivanis DA, Sismanopoulos N, Zhang B, Asadi S, Vasiadi M, Weng Z, Miniati A, Kalogeromitros D. Mast cells and inflammation. Biochimica et biophysica acta. 2012; 1822:21-33.

2. Zhang T, Finn DF, Barlow JW, Walsh JJ. Mast cell stabilizers. European journal of pharmacology. 2016; 778:158-68.

3. Elinav E, Nowarski R, Thaiss CA, Hu B, Jin C, Flavell RA. Inflammation-induced cancer: crosstalk between tumours, immune cells and microorganisms. Nature reviews. Cancer. 2013; 13:759-771.

4. Ribatti D. Mast cells in lymphomas. Critical reviews in oncology/hematology. 2016; 101:207-12.

5. Marinaccio C, Nico B, Maiorano E, Specchia G, Ribatti D. Insights in hodgkin lymphoma angiogenesis. Leukemia research.2014; 38:857-861. 
6. Melillo RM, Guarino V, Avilla E, Galdiero MR, Liotti F, Prevete N, Rossi FW, Basolo F, Ugolini C, de Paulis A, Santoro M, Marone G. Mast cells have a protumorigenic role in human thyroid cancer. Oncogene.2010; 29:62036215.

7. Pittoni P, Colombo MP. The dark side of mast cell-targeted therapy in prostate cancer. Cancer research.2012; 72:831835.

8. Ma Y, Hwang RF, Logsdon CD, Ullrich SE. Dynamic mast cell-stromal cell interactions promote growth of pancreatic cancer. Cancer research. 2013; 73:3927-3937.

9. Visciano C, Prevete N, Liotti F, Marone G. Tumorassociated mast cells in thyroid cancer. International journal of endocrinology. 2015; 2015:705169.

10. Gilfillan AM, Tkaczyk C. Integrated signalling pathways for mast-cell activation. Nature reviews. Immunology. 2006; 6:218-230.

11. Gao ZG, Ding Y, Jacobson KA. UDP-glucose acting at $\mathrm{P} 2 \mathrm{Y} 14$ receptors is a mediator of mast cell degranulation. Biochemical pharmacology. 2010; 79:873-879.

12. Gao ZG, Wei Q, Jayasekara MP, Jacobson KA. The role of P2Y14 and other P2Y receptors in degranulation of human LAD2 mast cells. Purinergic signalling. 2013; 9:31-40.

13. Ciruela F, Fernandez-Duenas V, Jacobson KA. Lighting up $\mathrm{G}$ protein-coupled purinergic receptors with engineered fluorescent ligands. Neuropharmacology. 2015; 98:58-67.

14. Burnstock G. Purine and pyrimidine receptors. Cellular and molecular life sciences. 2007; 64:1471-1483.

15. Kennedy C, Qi AD, Herold CL, Harden TK, Nicholas RA. $\mathrm{ATP}$, an agonist at the rat $\mathrm{P} 2 \mathrm{Y} 4$ receptor, is an antagonist at the human P2Y4 receptor. Molecular pharmacology. 2000; 57:926-931.

16. Abbracchio MP, Boeynaems JM, Barnard EA, Boyer JL, Kennedy C, Miras-Portugal MT, King BF, Gachet C, Jacobson KA, Weisman GA, Burnstock G. Characterization of the UDP-glucose receptor (re-named here the P2Y14 receptor) adds diversity to the $\mathrm{P} 2 \mathrm{Y}$ receptor family.Trends in pharmacological sciences. 2003; 4:52-55.

17. Abbracchio MP, Burnstock G, Boeynaems JM, Barnard EA, Boyer JL, Kennedy C, Knight GE, Fumagalli M, Gachet C, Jacobson KA, Weisman GA., 2006. International Union of Pharmacology LVIII: update on the P2Y G proteincoupled nucleotide receptors: from molecular mechanisms and pathophysiology to therapy.Pharmacological reviews. 2006; 58:281-341.

18. Bulanova E, Bulfone-Paus S. P2 receptor-mediated signaling in mast cell biology. Purinergic signalling. 2010; 6:3-17.

19. Azroyan A, Cortez-Retamozo V, Bouley R, Liberman R, Ruan YC, Kiselev E, Jacobson KA, Pittet MJ, Brown $\mathrm{D}$, Breton S. Renal intercalated cells sense and mediate inflammation via the P2Y14 receptor. PloS one. 2015; 10:10:e0121419.

20. Chambers JK, Macdonald LE, Sarau HM, Ames RS,
Freeman K, Foley JJ, Zhu Y, McLaughlin MM, Murdock P, McMillan L, Trill J, Swift A, Aiyar N, Taylor P,Vawter L, Naheed S, Szekeres P, Hervieu G, Scott C, Watson JM, Murphy AJ, Duzic E, Klein C, Bergsma DJ, Wilson S, Livi GP. A G protein-coupled receptor for UDP-glucose. The Journal of biological chemistry. 2000; 275:10767-10771.

21. Freeman K, Tsui P, Moore D, Emson PC, Vawter L, Naheed S, Lane P, Bawagan H, Herrity N, Murphy K, Sarau HM, Ames RS, Wilson S, Livi GP, Chambers JK. Cloning, pharmacology, and tissue distribution of G-protein-coupled receptor GPR105 (KIAA0001) rodent orthologs.Genomics. 2001; 78:124-128.

22. Harden TK, Sesma JI, Fricks IP, Lazarowski ER. Signalling and pharmacological properties of the $\mathrm{P} 2 \mathrm{Y}$ receptor. Acta physiologica. 2010; 199:149-160.

23. Hamel M, Henault M, Hyjazie H, Morin N, Bayly C, Skorey K, Therien AG, Mancini J, Brideau C, Kargman S. Discovery of novel P2Y14 agonist and antagonist using conventional and nonconventional methods. Journal of biomolecular screening. 2011; 16:1098-1105.

24. Carter RL, Fricks IP, Barrett MO, Burianek LE, Zhou Y, Ko H, Das A, Jacobson KA, Lazarowski ER, Harden TK. Quantification of Gi-mediated inhibition of adenylyl cyclase activity reveals that UDP is a potent agonist of the human P2Y14 receptor. Molecular pharmacology. 2009; 76:13411348.

25. Ko H, Fricks I, Ivanov AA, Harden TK, Jacobson KA. Structure-activity relationship of uridine 5'-diphosphoglucose analogues as agonists of the human P2Y14 receptor. Journal of medicinal chemistry. 2007; 50: 2030-2039.

26. Das A, Ko H, Burianek LE, Barrett MO, Harden TK, Jacobson KA. Human P2Y14 receptor agonists: truncation of the hexose moiety of uridine-5'-diphosphoglucose and its replacement with alkyl and aryl groups. Journal of medicinal chemistry. 2010; 53:471-480.

27. Gendaszewska-Darmach E, Szustak M. Thymidine 5'-O-monophosphorothioate induces HeLa cell migration by activation of the P2Y6 receptor. Purinergic signalling. 2016; 12:199-209.

28. Gendaszewska-Darmach E, Maszewska M, Zaklos M, Koziolkiewicz M. Degradation of extracellular nucleotides and their analogs in HeLa and HUVEC cell cultures. Acta biochimica Polonica. 2003; 50: 973-984.

29. Lazarowski ER, Shea DA, Boucher RC, Harden TK. Release of cellular UDP-glucose as a potential extracellular signaling molecule. Molecular pharmacology. 2003; 63:1190-1197.

30. Lazarowski ER, Harden TK. UDP-sugars as extracellular signaling molecules: cellular and physiologic consequences of P2Y14 receptor activation. Molecular pharmacology. 2015; 88:151-160.

31. Arase T, Uchida H, Kajitani T, Ono M, Tamaki K, Oda H, Nishikawa S, Kagami M, Nagashima T, Masuda H, 
Asada H, Yoshimura Y, Maruyama T. The UDP-glucose receptor P2RY14 triggers innate mucosal immunity in the female reproductive tract by inducing IL-8. Journal of immunology. 2009; 182:7074-7084.

32. Sesma JI, Kreda SM, Steinckwich-Besancon N, Dang H, García-Mata R, Harden TK, Lazarowski ER. The UDP-sugar-sensing P2Y14 receptor promotes Rhomediated signaling and chemotaxis in human neutrophils. American journal of physiology. Cell physiology. 2012; 303:C490-C498.

33. Moore DJ, Murdock PR, Watson JM, Faull RL, Waldvogel HJ, Szekeres PG, Wilson S, Freeman KB, Emson PC. GPR105, a novel Gi/o-coupled UDP-glucose receptor expressed on brain glia and peripheral immune cells, is regulated by immunologic challenge: possible role in neuroimmune function. Brain research. Molecular brain research. 2003; 118, 10-23.

34. Xu J, Morinaga H, Oh D, Li P, Chen A, Talukdar S, Lazarowski E, Olefsky JM, Kim JJ. GPR105 ablation prevents inflammation and improves insulin sensitivity in mice with diet-induced obesity. Journal of immunology. 2012; 189:1992-1999.

35. Eigenbrodt E, Reinacher M, Scheefers-Borchel U, Scheefers H, Friis R. Double role for pyruvate kinase type M2 in the expansion of phosphometabolite pools found in tumor cells. Critical reviews in oncogenesis. 1992; 3:91-115.

36. Fricks IP, Carter RL, Lazarowski ER, Harden TK. Gi-dependent cell signaling responses of the human P2Y14 receptor in model cell systems. The Journal of pharmacology and experimental therapeutics. 2009; 330:162-168.

37. Guay D, Beaulieu C, Belley M, Crane SN, DeLuca J, Gareau Y, Hamel M, Henault M, Hyjazie H, Kargman S, Chan CC, Xu L, Gordon R, Li L, Mamane Y, Morin N, Mancini J, Thérien M, Tranmer G, Truong VL, Wang Z, Black WC. Synthesis and SAR of pyrimidine-based, nonnucleotide P2Y14 receptor antagonists. Bioorganic \& medicinal chemistry letters. 2011; 21:2832-2835.

38. Gauthier JY, Belley M, Deschênes D, Fournier JF, Gagné S, Gareau Y, Hamel M, Hénault M, Hyjazie H, Kargman S, Lavallée G, Levesque JF, Li L, Mamane Y,Mancini J, Morin N, Mulrooney E, Robichaud J, Thérien M, Tranmer G, Wang Z, Wu J, Black WC. The identification of 4,7-disubstituted naphthoic acid derivatives as UDPcompetitive antagonists of P2Y14. Bioorganic \& medicinal chemistry letters. 2011; 21:2836-2839.
39. Barrett MO, Sesma JI, Ball CB, Jayasekara PS, Jacobson KA, Lazarowski ER, Harden TK. A selective high-affinity antagonist of the P2Y14 receptor inhibits UDP-glucosestimulated chemotaxis of human neutrophils. Molecular pharmacology. 2013; 84: 41-49.

40. Robichaud J, Fournier JF, Gagné S, Gauthier JY, Hamel M, Han Y, Hénault M, Kargman S, Levesque JF, Mamane Y, Mancini J, Morin N, Mulrooney E, Wu J,Black WC. Applying the pro-drug approach to afford highly bioavailable antagonists of P2Y(14). Bioorganic \& medicinal chemistry letters. 2011;21:4366-4368.

41. von Kügelgen I, Hoffmann K. Pharmacology and structure of P2Y receptors. Neuropharmacology. 2015; pii: S00283908(15)30153-2.

42. Kiselev E, Barrett MO, Katritch V, Paoletta S, Weitzer CD, Brown KA, Hammes E, Yin AL, Zhao Q, Stevens RC, Harden TK, Jacobson KA. Exploring a 2-naphthoic acid template for the structure-based design of P2Y14 receptor antagonist molecular probes. ACS chemical biology. 2014; 9:2833-2842.

43. Gao ZG, Ding Y, Jacobson KA. P2Y(13) receptor is responsible for ADP-mediated degranulation in RBL-2H3 rat mast cells. Pharmacological research. 2010; 62:500-505.

44. Communi D, Robaye B, Boeynaems JM. Pharmacological characterization of the human P2Y11 receptor. British journal of pharmacology. 1999; 128:1199-1206.

45. Trujillo K, Paoletta S, Kiselev E, Jacobson KA. Molecular modeling of the human P2Y14 receptor: A template for structure-based design of selective agonist ligands. Bioorganic \& medicinal chemistry. 2015; 23: 4056-4064.

46. Dertinger D, Behlen LS, Uhlenbeck OC. Using phosphorothioate-substituted RNA to investigate the thermodynamic role of phosphates in a sequence specific RNA-protein complex. Biochemistry. 2000; 39:55-63.

47. Kowalska J, Lewdorowicz M, Zuberek J, GrudzienNogalska E, Bojarska E, Stepinski J, Rhoads RE, Darzynkiewicz E, Davis RE, Jemielity J. Synthesis and characterization of mRNA cap analogs containing phosphorothioate substitutions that bind tightly to eIF4E and are resistant to the decapping pyrophosphatase DcpS. RNA. 2008; 14:1119-1131. 